\author{
포스트텐션을 도입한 넓은 보에서 기둥 폭 내부에 배근된 \\ 보강재의 정착비에 따른 비탄성 거동 평가 \\ 최윤철 ${ }^{1) \star} \cdot$ 임재형 ${ }^{2)}$ - 문정호 ${ }^{3)}$ - 이리형 ${ }^{1)}$ - 권기혁 ${ }^{4)}$ \\ 1) 한양대학교 건축공학과 ${ }^{2)}$ 우송공업대학 건축디자인과 ${ }^{3)}$ 한남대학교 건축공학과 ${ }^{4)}$ 서울시립대학교 건축공학과
}

(2004년 6월 30일 원고접수, 2004년 12월 22일 심사완료)

\title{
Inelastic Behavior of Post-tensioned Wide Beam System with different Reinforcement ratios within Column core
}

\author{
Yun-Cheul Choi ${ }^{1) *}$, Jae-Hyung Lim ${ }^{2)}$, Jeong-Ho Moon ${ }^{3)}$, Li-Hyung Lee ${ }^{1)}$, and Ki-Hyuk Kwon ${ }^{4)}$ \\ ${ }^{1)}$ Dept of Architectural Engineering, Hanyang University, Seoul, Korea \\ ${ }^{2)}$ Dept of Architectural Engineering, Woosong Technical College, Daejeon, Korea \\ ${ }^{3)}$ Dept of Architectural Engineering, Hannam University, Daejeon, Korea \\ ${ }^{4)}$ Dept of Architectural Engineering, University of Seoul, Seoul, Korea
}

(Received June 20, 2004, Accepted, December 22, 2004)

\begin{abstract}
Post-tensioned Precast concrete System(PPS) consists of U-shaped precast wide beams and concrete column. The continuity of beam-column joint is provided with floor concrete cast on the PC shell beam and post-tensioning. The purpose of this paper is to evaluate the response of PPS interior beam-column joint subjected to cyclic lateral loading. To this end, an experimental investigation was performed with three half-scale specimens of interior connection. The design parameters are the amount of beam reinforcement placed inside the joint core. The test results showed that cracks were distributed well without any significant degradation of strength and ductility. Also, it was found that the prestressing may affect to alter the torsional crack angle. And the specimens sufficiently resist up to limiting drift ratio of 0.035 in accordance with the provisional by ACI of acceptance criteria for concrete special moment frames.
\end{abstract}

Keywords : post-tensioned, precast, wide beam, beam-column connection

\section{1. 서 론}

본 연구는 구조물이 고층화될 경우 동일한 건물높이에 서 층수의 증가를 위하여 춤이 낮은 $\mathrm{PC} \mathrm{U} \mathrm{U}$ 형의 넓은 보 (wide beam)를 사용하며, 접합부에서 연속성을 확보하고 긴장재의 장력을 이용하여 장스팬의 구조형식을 이룰 수 있도록 부착방식의 포스트텐션을 도입한 "PPS(Posttensioned Precast concrete System)개발"'” 의 일부이다.

현재 지진지역에서 넓은 보의 사웅을 제한하는 규정은 보의 유효폭으로서 $b_{c}+1.5 h_{b}$ 로 한정하고 있다. 그러나 PPS 공법에 적용된 넓은 보-기둥 접합부에서 보 길이 방향 보 강근의 일부분은 기둥 폭의 외부에 배근되며, 기둥 폭 외 부에 배근된 철근은 지진에 의해 유발되는 황력을 받을 때 부착력 상실 등과 같은 거동톡성을 나타낸달. 특히

* Corresponding author

E-mail : 21ycchoi@netian.com

(C)2005 by Korea Concrete Institute
모멘트 저항 골조에서 넓은 보 시스템을 적용할 경우 일 반적인 문제는 기둥 폭 외부에서 발생하는 불균형모멘트에 의한 비틀림 균열이다. 이 균열은 스트럿-타이 메커니즘에 의해 불균형 모멘트를 접합부로 전달하는 기둥 폭 외부의 보강재 양이나 위치에 따라 다르게 나타난다. ${ }^{3)}$ 이 때문에 일부 연구자들은 ${ }^{4-5)}$ 디본딩(debonding) 방식으로 보강재와 콘크리트의 부착력을 제거하여 철근이 독립적으로 거동하 도록 함으로써 비틀림 균열을 제어하고자 하였다.

따라서 본 연구에서는 포스트텐션을 도입한 넓은 보-기 둥 내부접합부에 대하여 기둥 폭 내부에 위치한 보강재의 정착비를 달리함으로서 나타나는 거동특성을 규명하고자 실험을 실시하였다. 특히 $\mathrm{PC}$ 구조의 문제점으로 제기되고 있는 일체성 확보와 장스팬의 구조형식을 위하여 도입된 긴장재를 기둥 폭 내부에서 철근과 함께 그 정착된 양을 달리 배치함으로서 각각의 경우 나타나는 거동특성을 비 교하여 적절한 정착비를 분석하였으며 $\mathrm{PC}$ 구조의 성능평 가 방법 ${ }^{6)}$ 을 이용하여 접합부의 내진성능을 평가하여 본 시스템의 안전성과 시공성을 높이는 것을 목표로 하였다. 


\section{2. 기존연구}

넓은 보와 관련하여 현행기준 $\left(\mathrm{ACl}^{7}, \mathrm{NZS}^{8}\right)$ 에서는 보의 유효폭에 대하여 규정하고 있어 이에 관한 연구가 넓은 보/기둥 유효폭비를 중심으로 진행되어 왔다.

Hatamoto동은 기둥 폭 내부의 철근비를 달리한 일체 식 구조의 넓은 보-기둥 접합부 실험에서 기둥 폭 내부의 정착비에 따른 거동특성을 규명하고자 하였다. 그 결과 기 둥 폭 내부의 정착비가 $33 \%$ 인 실험체의 경우 접합부의 기둥 폭 외부에서 높은 비틀림 응력과 회전변형이 발생함 을 확인하였다. 또한 접합부의 기둥 폭 외부에서 철근의 응력이 급격히 감소하며 비틀림 균열이 발생하였으며, 하 중-변위 곡선에서 핀칭현상과 함께 낮은 에너지 소산 능 력을 발휘하는 것으로 보고하고 있다.

Stehle ${ }^{4 /}$ 는 넓은 보/기둥의 폭비가 4.8 인 내부접합부에서 전단균열 및 부분적으로 발생하는 불균형모멘트를 제어하 고자 기둥 폭 외부의 보강근에 디본딩 방식을 채택하여 실험을 수행하였으며, 그 결과를 일체식 콘크리트 구조의 넓은 보-기둥 접합부와 비교하였다. 그 결과 기둥면에서 발달된 비틀림 균열이 많이 감소하였으며 전체적인 강도 가 증가하여 모멘트 저항 골조구조로써 지진지역에서도 사용이 가능함을 보고하고 있다.

$\mathrm{Siah}^{5)}$ 는 횡하중에 대하여 포스트텐션된 넓은 보-기둥 접합부에서 넓은 보의 거동과 비틀림 균열을 확인하기 위 한 실험을 실시하였으며, 이 결과를 바탕으로 실험체 상세 가 유사한 기존의 철근콘크리트 넓은 보 실험체와 비교하 였다. 그 결과 PS가 보의 축방향으로 작용함으로써 축방 향에 대한 균열을 제어하며, 비틀림 균열의 각도를 변화시 키는 효과가 있음을 확인하였다. 또한 일체식 구조에 비해

Table 1 Specimen and prototype (unit : m)

\begin{tabular}{c|c|c}
\hline Type & Prototype & Specimen \\
\hline \hline Plan & $10 \times 8$ & $5 \times 4$ \\
\hline Column & $0.6 \times 0.6$ & $0.3 \times 0.3$ \\
\hline Beam & $1.0 \times 0.4$ & $0.5 \times 0.2$ (reference type) \\
\hline Height & 3.2 & 1.6 \\
\hline Beam length & 10 & 5 \\
\hline
\end{tabular}

$11 \%$ 이상의 더 큰 강성을 발휘하였으며, 접합부의 내진성 능을 개선하였다고 보고하고 있다.

이와 같이 넓은 보-기둥 접합부에 관한 기존 연구들은 일체식 구조에서 보 철근의 정착방법과 포스트텐션이 도입 된 구조물의 거동특성에 대하여 연구가 진행 되었으나, 기 둥 폭 내·외부에 위치한 보강재의 정착비가 구조체 전체 적 거동에 미치는 영향에 대해서는 미미한 실정이다.

\section{3. 실 험}

\section{1 실험체 계획}

넓은 보-기둥 접합부에서는 일반적인 형태의 보-기둥 접합부와는 달리 넓은 보의 보강재 일부분이 기둥 폭 외부 에 정착하게 되며, 폭 외부에 정착되어진 보강재의 기여정 도에 따라 전체적인 거동특성이 다르게 나타난다. 그리고 넓은 보와 관련하여 현행 $\mathrm{ACl}$ 기준에는 넓은 보-기둥의 폭 비를 제한하고 있으나 기둥 폭 내·외부에 위치한 보강재 의 정착비에 관해서는 뚜렷한 기준이 설정되어 있지 않다. 따라서 본 연구의 주요 실험 변수는 넓은 보-기둥의 접합 부에서 기둥 폭 내 - 외부에 위치한 보강근의 정착비로 선정 하였으며, 강한 기둥-약한 보의 이상적인 붕괴기구를 확보 할 수 있도록 $\mathrm{ACI}$ 기준에서 규정하고 있는 $\Sigma M_{c}>1.4 M_{b}$ 에 따라 계획하였다. 이에 따라, Fig. 1 과 같이 $10 \mathrm{~m} \times 8 \mathrm{~m}$ 의 기 본 모듈로 이루어진 20 층 규모의 사무소를 대상건물로 선정 하였으며, 철근 콘크리트 골조의 성능 평가 허용기군하에 따 라 실험체를 제작하여 실험을 실시하였다.

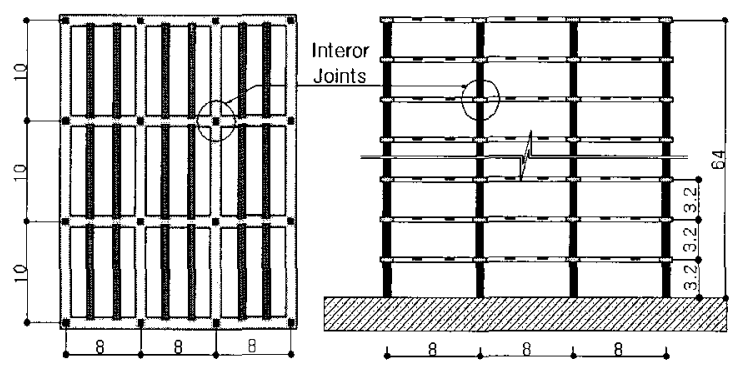

Fig. 1 Prototype frame (unit : m)

Table 2 Specimen list

\begin{tabular}{|c|c|c|c|c|c|c|c|}
\hline \multirow{2}{*}{ Type } & \multicolumn{3}{|c|}{ Beam } & \multirow{2}{*}{$\begin{array}{c}\text { Beam-column } \\
\text { width ration }\left(b_{w} / b_{c}\right)\end{array}$} & \multirow{2}{*}{$\begin{array}{c}\text { Moment ratio } \\
\qquad\left(\frac{\Sigma M_{c}}{\Sigma M_{b}}\right)\end{array}$} & \multirow{2}{*}{$\begin{array}{l}\text { Anchored ratio in } \\
\text { column core }(\%)\end{array}$} & \multirow{2}{*}{$\begin{array}{l}\text { Tendon anchored in } \\
\text { column core (EA) }\end{array}$} \\
\hline & Top & Bottom & Tendon & & & & \\
\hline IJH-1 & \multirow{2}{*}{ 4-D13 } & \multirow{3}{*}{$4-\mathrm{D} 13$} & \multirow{2}{*}{$8-\phi 6$} & \multirow{3}{*}{1.67} & \multirow{2}{*}{2} & 63.9 & 6 \\
\hline IJH-2 & & & & & & 36.1 & 2 \\
\hline $\mathrm{IJH}-3$ & $6-\mathrm{D} 13$ & & $5-\phi 6$ & & 2.3 & 63.9 & 5 \\
\hline Common & $\begin{array}{l}\text { Beam } \\
\text { Column } \\
f_{c k}: 3\end{array}$ & $\begin{array}{l}\text { : struip } \\
\text { : section } \\
1.3 \mathrm{MPa}, A\end{array}$ & $\begin{array}{l}56 @ 100 \\
30 \times 30 c \\
x i a l \text { load }\end{array}$ & $\begin{array}{l}\text { Column depth/beam } \\
\text { m, Beam depth/colum } \\
: 309 \mathrm{kN}\left(0.1 f_{c k} A_{g}\right)\end{array}$ & $\begin{array}{l}\operatorname{ar}\left(h_{c} / d_{b}\right)=23.07 \\
\operatorname{bar}\left(h_{b} / d_{b}\right)=12.5\end{array}$ & ngitudinal bar 8-D16, & hoop D6@100 \\
\hline
\end{tabular}




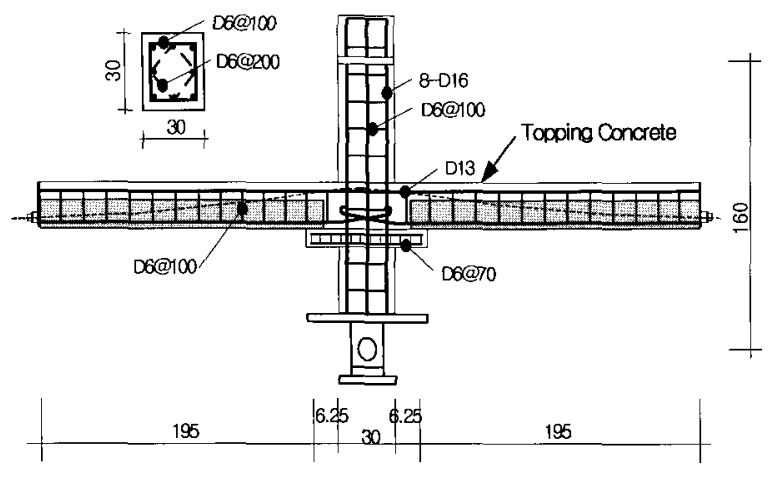

(a) Typical details of specimen

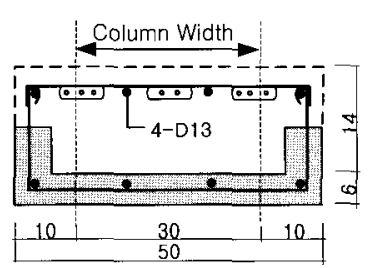

$\langle$ End $\rangle$

(b) $\mathrm{IJH}-1$

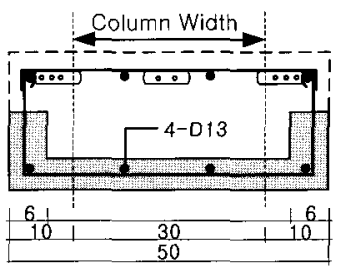

$\langle$ End $\rangle$

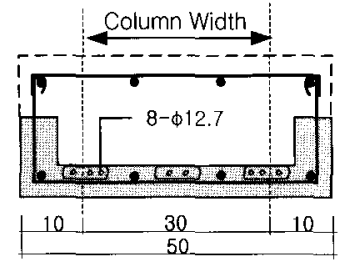

〈Middle

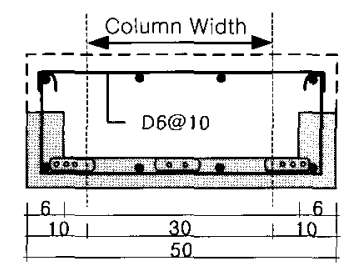

$\langle$ Middle $\rangle$ (c) IJH-2

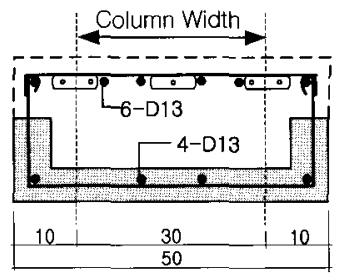

$\langle$ End $\rangle$

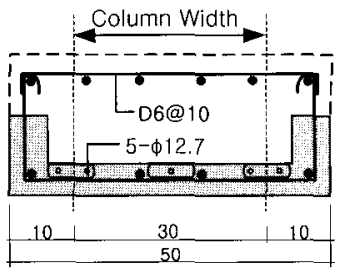

$\langle$ Middle $\rangle$ (d) $\mathrm{IJH}-3$

Fig. 2 Details of specimen (unit: $\mathrm{cm}$ )

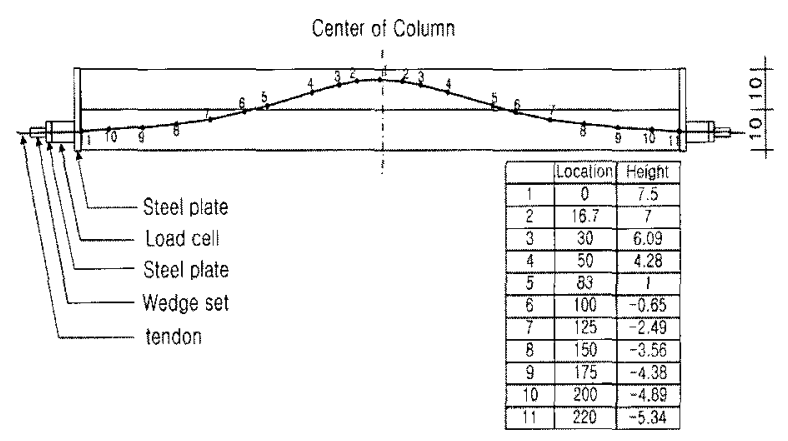

Fig. 3 Tendon profile (unit: $\mathrm{cm}$ )
실험체는 넓은 보의 폭과 관련한 현행 $\mathrm{ACI}$ 기준을 만 족하도록 최대폭비 1.67 을 유지하였으며, 기둥 폭 내·외 부의 정착비를 달리하였다. 실험체는 실제 구조물에 대하 여 $1 / 2$ 축소모델로서 기둥의 크기는 $30 \mathrm{~cm} \times 30 \mathrm{~cm}$, 보 길이 는 $500 \mathrm{~cm}$ 의 내부 접합부를 모델링한 3 개의 실험체를 제 작하였다.

각 변수별 실험체의 세부상세는 일체식 구조의 넓은 보 에서 기둥 폭 내부의 정착비를 $33 \%$ 로 유지하였을때 비틀 림 균열이 발생한 Hatomoto ${ }^{3)}$ 의 연구결과를 바탕으로 본 연구에서도 기둥 폭 내부에 보강재의 정착비를 $63.9 \%$ 와 $36.1 \%$ 로 달리 계획하였다. 또한 긴장재와 철근의 양을 달 리하여 기둥 폭 내부의 정착비를 $63.9 \%$ 로 유지시킨 실험 체도 포함하였다. 실험체 일람 및 변수는 Table 2 와 같으 며 실험체 형상 및 배근 사항은 Fig. 2에 나타내었다. 그 리고 긴장재의 조립은 연속성을 고려하여 Fig. 3과 같이 곡선배치 하였다.

\section{2 재료시험}

실험체 제작시 사용된 콘크리트의 28 일 압축강도는 평 균 $35 \mathrm{MPa}$ 으로 나타났으며, 강재의 재료시험결과는 각각 Tables 3과 4에 나타내었다.

\section{3 실험체 설치 상황}

실험체는 Fig. 4와 같이 설치하였다. 그림에서와 같이 보의 양 단부에는 회전이 가능한 유압힌지를 부착하고 로 드 셀(load cell)을 설치하였다. 기둥 양 단부에는 플레이 트 판을 이용하여 강봉으로 축력이 작용하도록 하였으며, 하부에는 회전이 가능하도록 힌지를 설치하였다. 실험체의 가력은 25 tonf 엑츄에이터를 사용하여 기둥 상부에서 수 평으로 반복가력 하였다. 가력방법은 부재각 $(\mathrm{R})$ 에 따라 $1 / 500,1 / 300,1 / 150,1 / 100,1 / 75,1 / 50,1 / 33,1 / 25,1 / 20$ 의

Table 3 Material properties of tendon (unit : MPa)

\begin{tabular}{c|c|c|c|c}
\hline Type & $\begin{array}{c}\text { Yield } \\
\text { strength }\end{array}$ & $\begin{array}{c}\text { Tensile } \\
\text { strength }\end{array}$ & $\begin{array}{c}\text { Module of } \\
\text { elasticity }\end{array}$ & $\begin{array}{c}\text { Yield strain } \\
\left(\times 10^{-6}\right)\end{array}$ \\
\hline \hline $\begin{array}{l}3-\text { wire } \\
\text { strand }\end{array}$ & 1876 & 2109 & $1.88 \times 10^{5}$ & 9976 \\
\hline
\end{tabular}

Table 4 Material properties of rebars (unit : MPa)

\begin{tabular}{c|c|c|c|c}
\hline Type & $\begin{array}{c}\text { Yield } \\
\text { strength }\end{array}$ & $\begin{array}{c}\text { Tensile } \\
\text { strength }\end{array}$ & $\begin{array}{c}\text { Module of } \\
\text { elasticity }\end{array}$ & $\begin{array}{c}\text { Elongation } \\
\text { ratio (\%) }\end{array}$ \\
\hline \hline D6 (SD40) & 388 & 545 & $1.89 \times 10^{5}$ & 15 \\
\hline D10 (SD40) & 415 & 603 & $1.97 \times 10^{5}$ & 17 \\
\hline D13 (SD40) & 427 & 633 & $2.20 \times 10^{5}$ & 17 \\
\hline D16 (SD40) & 440 & 631 & $2.12 \times 10^{5}$ & 17 \\
\hline
\end{tabular}




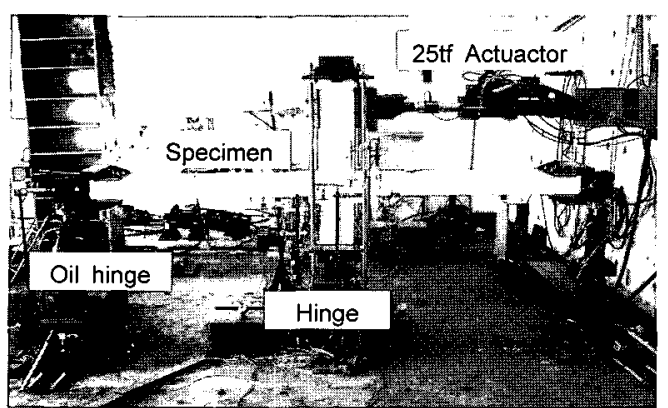

Fig. 4 Experimntal setup

순으로 점증 반복가력 하였으며, 각각 3 싸이클씩 반복가력 하면서 부재각에 따른 변위제어 방식으로 가력하였다. 각 지점의 변위 측정과 동시에 기둥 폭 내·외부에 정착된 보 철근의 변형률도 측정하였다.

\section{4. 실험 결과 및 분석}

\section{1 균열 및 파괴상황}

모든 실험체에서 접합부의 전단파괴 보다는 넓은 보의 휨파괴가 주요 파괴모드로 나타났으며, 각 실험체의 파괴 형상은 Fig. 5 와 같다. 파괴형태를 살펴보면, 대부분의 실 험체들에서 초기균열의 발생위치는 보와 기둥의 접합면에 서 발생하였으며, 항복하중에 도달할 때까지 좌·우로 일 정한 간격의 수직 휨 균열이 보의 중앙부로 확산되는 양 상을 보였다. 항복하중 이후에는 휨 균열의 확산범위가 소 성힌지 범위에서 한정되고, 기존에 발생된 균열과 균열사 이에 새로운 균열과 함께 균열폭이 더욱 넓어지며 최종 파괴 되었다.

이상과 같이 본 연구에서 실험된 실험체의 최종파괴 현 상은 변수에 무관하게 그 양상이 거의 동일하였으나 부재 각이 증가됨에 따라 접합부의 기둥 폭 외부에서 발생된 균열의 진행은 다소 차이가 있었다. 기둥 폭 내부의 정착 비가 약 $65 \%$ 인 $\mathrm{IJH}-1,3$ 의 경우 보의 길이 방향에서 나 타난 휨 균열과 평행하게 균열이 발생한 반면, 기둥 폭 내 부의 정착비가 약 $35 \%$ 인 $\mathrm{IJH}-2$ 의 경우 Fig. $5(\mathrm{~b})$ 와 같이 부재각 $3 \%$ 에서 기둥면과 약 $45^{\circ}$ 의 대각선 방향으로 미소 균열이 발생하였다. 또한 이때 내력의 증가가 다소 주춤하 였으나 발생된 균열은 부재각 $3.5 \%$ 이후 보의 길이방향으 로 더 이상 발전되지 않고, 실험체의 내력 역시 다시 증가 한 후 최종 파괴에 이르렀다. 이는 기둥 폭 내부의 정착비 에 따른 결과로 기둥 폭 내부에 정착비가 약 $35 \%$ 일 경우 반복가력 되는 동안 다소 미미하지만 접합부의 기둥 폭 외부에서 비틀림 균열이 발생하고 강성 역시 감소하였기 때문으로 판단되었다.

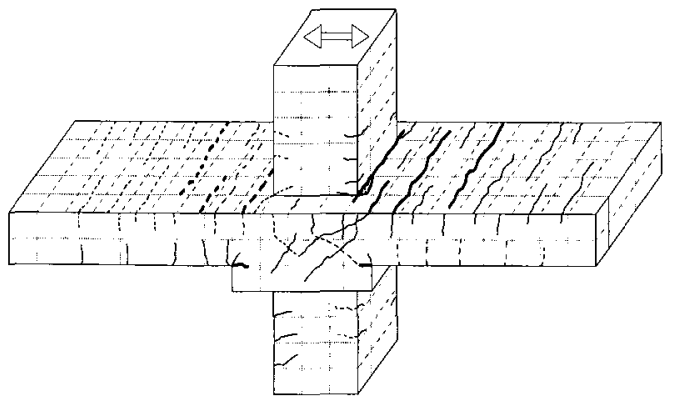

(a) $\mathrm{IJH}-1$

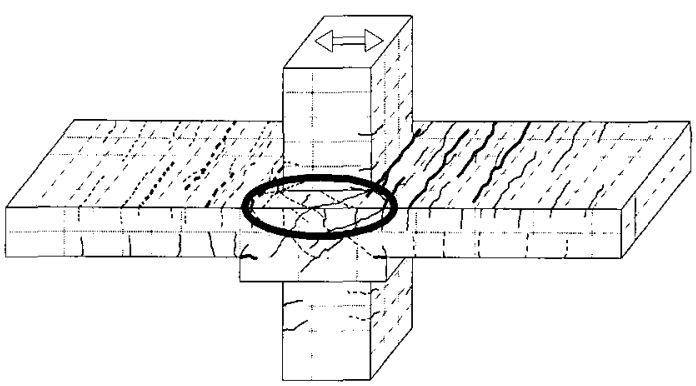

(b) $\mathrm{IJH}-2$

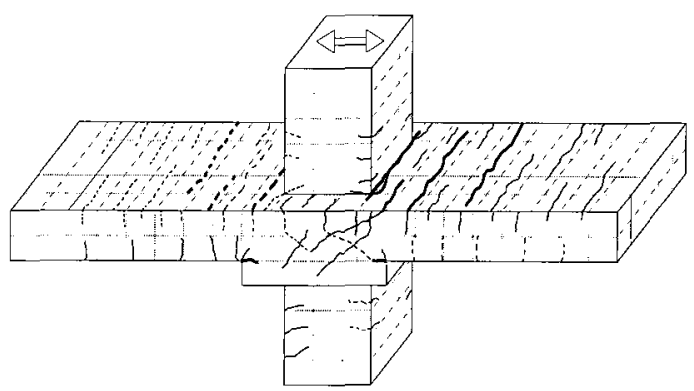

(c) $\mathrm{IJH}-3$

Fig. 5 Crack patterns of specimens

\section{2 하중-변위 곡선}

본 연구에서 실험된 실험체에 대한 점증반복가력의 하 중-변위 곡선을 Fig. 6에 나타내었다. 변위는 기둥의 가력 지점에서 측정한 값이다.

그림에서와 같이 기둥 폭 내부의 정착비를 변수로 한 모든 실험체는 설계변수에도 불구하고 부재각 $2.5 \%$ 까지 탄성적으로 거동하였으며 부재각 $1.5-2.5 \%$ 에 각각의 정-부 설계강도에 도달하였다. 또한 NEHRP에서 한계부 재각으로 권고하고 있는 $3.5 \%$ 까지 내력저하는 발생하지 않고 지속되었으며, 이후 부재각 $5 \%$ 에서 내력의 감소가 발생하는 연성적인 거동을 나타내고 있는데 이는 보강 재의 양이 압축측 콘크리트가 부담하는 압축력과 평형을 이루고 있기 때문으로 사료된다.

최대내력은 대체적으로 기둥 폭 내부의 정착비가 높은 
Table 5 Test results of specimen

\begin{tabular}{|c|c|c|c|c|c|c|c|c|}
\hline Specimens & $\begin{array}{c}P_{c r} \\
(\mathrm{kN})\end{array}$ & $\begin{array}{c}P_{y} \\
(\mathrm{kN})\end{array}$ & $\begin{array}{c}P_{u} \\
(\mathrm{kN})\end{array}$ & $\begin{array}{c}\text { THE } P_{u} \\
(\mathrm{kN})\end{array}$ & $\frac{P_{u}}{T_{H E} P_{u}}$ & $\begin{array}{c}\Delta_{\mathrm{y}} \\
(\mathrm{mm})\end{array}$ & $\begin{array}{c}\Delta_{\mathrm{u}} \\
(\mathrm{mm})\end{array}$ & y \\
\hline IJH-1 & 23.5 & 55.9 & 85.3 & 68.6 & 1.24 & 18.6 & 64 & 3.44 \\
\hline IJH -2 & 13.7 & 53.9 & 87.2 & 68.6 & 1.27 & 21.7 & 81.23 & 3.74 \\
\hline IJH -3 & 26.5 & 52.9 & 103.2 & 57.8 & 1.78 & 20.9 & 78.62 & 3.76 \\
\hline
\end{tabular}

$P_{c r}:$ initial crack load, $P_{u}:$ maximum strength(testing value) ${ }_{T H E} P_{u}:$ maximum strength(design value) $P_{y}:$ yield strength $\Delta_{\mathrm{y}}$ : displacement at $P_{y} \quad \Delta_{u}:$ displacement at $P_{u} \quad \mu$ : displacement ductility ratio

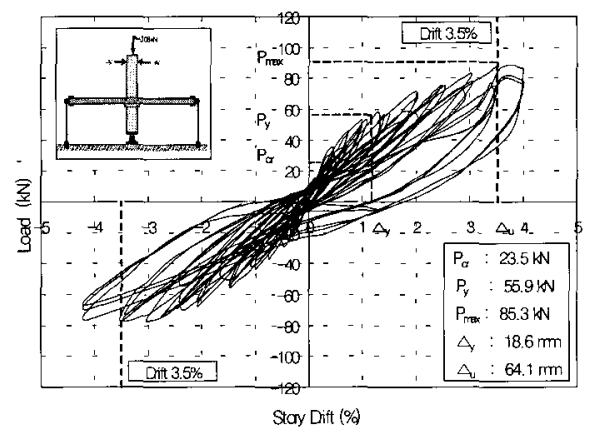

(a) $\mathrm{IJH}-1$

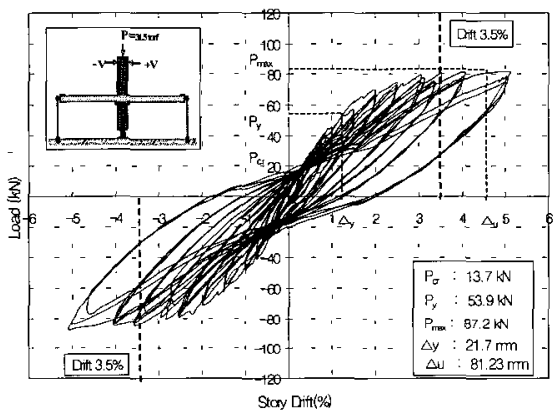

(b) $\mathrm{IJH}-2$

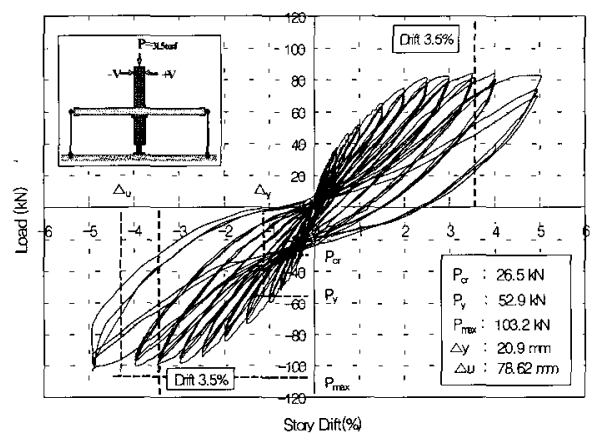

(c) $\mathrm{HH}-3$

Fig. 6 Load-displacement hysteresis loop

실험체에서 다소 높게 나타났다. 또한 기둥 폭 내부의 정 착비는 $65 \%$ 로 동일하나 긴장재와 철근의 양을 변화시킨 $\mathrm{IJH}-1,3$ 의 경우, 긴장재 보다 철근을 더 많이 배치한 $\mathrm{IJH}-3$ 실험체가 부가력예서 약 $15 \%$ 의 내력증가를 나타 내었다. 따라서 현행 $\mathrm{ACI}$ 기준에서 제한하는 넓은 보의
유효폭 내에서 기둥 폭 내부의 정착비가 35 65\%인 경우 내력은 유사하게 나타나며, 기둥 폭 내부의 정착비가 동일 할 경우 긴장재 보다 철근을 더 많이 배치한 경우가 내력 에 더 기여하는 것으로 나타났다.

지진하중을 받는 구조물의 비탄성 변형수준의 척도인 변위연성도는 최대하중에서의 변위에 대한 항복때의 변위 비로 나타내었다. Table 5에서 알 수 있듯이 기둥 폭 내 부의 정착비를 달리한 $\mathrm{IJH}-1,2,3$ 에서의 변위연성비는 $\mathrm{IJH}-1=3.44, \mathrm{IJH}-2=3.74, \mathrm{IJH}-3=3.76$ 으로서 기둥 폭 내부의 정착비가 약 $65 \%$ 이면서 철근을 더 많이 배치한 $\mathrm{IJH}-3$ 이 가장 높게 나타났으나, 변수별 실험체의 변위연성비는 거 의 유사하게 나타났다. 따라서 넓은 보-기둥 접합부는 연 성적인 거동을 나타내며, 변위연성비는 기둥 폭 내부의 정 착비와 관계가 적은 것으로 판단되었다.

\section{3 에너지소산면적}

실험체의 하중-변위 이력 곡선상의 면적으로 계산한 소 산에너지를 Figs. 7과 8에 나타내었다. Fig. 7은 단계별 소 산된 에너지를 각 부재각의 이력곡선이 차지하는 면적으 로 구해졌으며, Fig. 8은 해당 부재각까지의 에너지 소산 량을 정량적으로 합산하였다. Fig. 7에서와 같이 모든 실 험체가 가력초기부터 부재각 $1 \%$ 까지는 매우 유사한 소산 능력을 보였다. 이후 각 실험체는 매우 선형적으로 증가한 후 뚜렷한 감소현상을 나타내지 않았다. 기둥 폭 내부의 정착비가 $35 \%$ 인 $\mathrm{IJH}-2$ 실험체가 낮은 최대내력에도 불 구하고 정착비가 $65 \%$ 인 $\mathrm{IJH}-1,3$ 실험체에 비하여 각 부 재각에서 약 $5 \%$ 정도 높게 나타났다. 또한 기둥 폭 내부 에 철근과 긴장재의 양을 달리하여 동일정착비로 계획한 $\mathrm{IJH}-1,3$ 의 경우 각 부재각에서 거의 동일한 에너지 소산 능력을 나타내었다.

누적된 에너지 소산량은 Fig. 8과 같이 부재각 $1.5 \%$ 까 지 모든 실험체가 거의 비슷하였으나 이후 실험체들 간에 다소 차이가 나타났다. 최종적으로는 $\mathrm{IJH}-2$ 실험체가 $4068 \mathrm{tf} \cdot$ $\mathrm{mm}$ 로 $\mathrm{IJH}-1,3$ 실험체의 $2641 \mathrm{tf} \cdot \mathrm{mm}, 3533 \mathrm{tf} \cdot \mathrm{mm}$ 보다 약 $54 \%, 30 \%$ 가량 큰 에너지 소산능력을 보였다. 그러나 이는 $\mathrm{IJH}-1$ 실험체는 부재각 $4 \%, \mathrm{IJH}-2,3$ 은 부재각 $5 \%$ 까지 실험된 결과로서 $\mathrm{IJH}-1$ 실험체가 실험된 부재각 
$4 \%$ 까지의 누적 에너지 소산면적을 비교하여 보면, $\mathrm{IJH}-2$ 실험체가 $\mathrm{IJH}-1,3$ 실험체에 비해 약 $7 \%$ 와 $10 \%$ 정도 매 우 미미한 향상을 나타냈다.

따라서 포스트텐션을 도입한 넓은 보-기둥 접합부에서 기둥 폭 내부의 정착비가 $35-65 \%$ 인 경우 입력되는 지진 에너지는 비탄성 이력거동을 통하여 유사한 소산능력을 발휘하는 것으로 나타났다.

\section{4 넓은 보의 비틀림}

넓은 보-기둥의 부분구조체의 거동은 접합부의 기둥 폭 외부에서 발생한 모멘트가 기둥 폭 내부로 전달되는 정도 에 따라 다르게 나타난다. 또한 넓은 보의 기둥 폭 외부에 서는 불균형모멘트에 의한 비틀림균열이 발생하게 되며, 이 균열은 기둥 폭 외부에 정착된 보강재의 정착비에 따 라 다르게 나타난다 $)^{5)^{4}}$.

현행 $\mathrm{ACI}$ 기준에서는 프리스트레스트 부재에 대한 균 열 비틀림모멘트는 (1)식과 같이 규정하고 있다.

$$
T_{c r}=4 \sqrt{f_{c k}}\left(\frac{A_{C P}^{2}}{p_{c p}}\right) \sqrt{1+\frac{f_{p c}}{4 \sqrt{f_{c k}}}}
$$

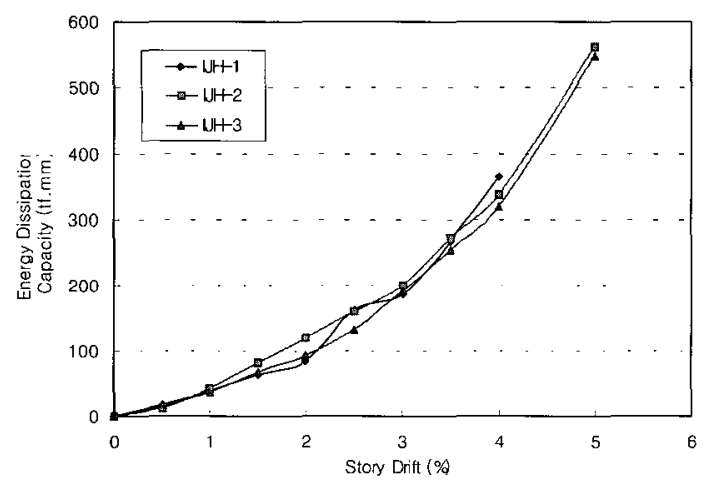

Fig. 7 Energy dissipation capacity

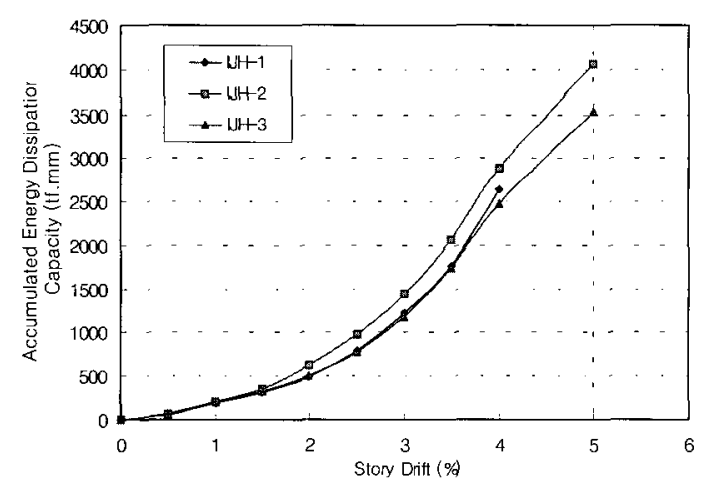

Fig. 8 Comulative energy
여기서, $A_{c p}$ : 콘크리트 단면적,

$P_{c p}$ : 콘크리트 단면 둘레길이,

$f_{p x}$ : 단면도심의 콘크리트 압축응력

교차보가 없는 넓은 보의 비틀림 강도는 Hatamoto등 ${ }^{3)}$ 이 일체식 구조의 넓은 보-기둥 접합부 관련 연구에서 유 효한 비틀림 강도식으로 제안하고 있는 Yoshikazu kanoh 등")의 식 (2)과 같이 나타닐 수 있다.

$$
\tau^{\tau_{t}}=24 \sqrt{f_{c k}} \quad \text { psi } \quad\left(6.36 \sqrt{f_{c k}} \mathrm{~kg} / \mathrm{cm}^{2}\right)
$$

또한, 기둥 폭 외부에 위치한 비틀림응력은 다음과 같이 나타내고 있다.

$$
e^{\tau_{t}}=\frac{M_{t}}{W_{t}}
$$

여기서, $M_{t}$ : 비틀림모멘트, $W_{t}$ : 소성 극 2 차 모멘트,

$Q_{b}:$ 보의 전단력, $l_{b}:$ 보의 길이,

$M_{t}=Q_{b} \times l_{b} \times($ 폭 외부의 철근량/보의 전체 철근량),

$W_{t}=\frac{1}{2} \times d_{b}^{2} \times d_{c} \times\left(1-\frac{1}{3} \times \frac{d_{b}}{d_{c}}\right)$,

$d_{b}:$ 보의 깊이, $d_{c}$ : 기둥의 깊이

식 (2), (3)에 따라 본 연구에 적용된 실험체의 비틀림강 도 $\left({ }_{c} \tau_{t}\right)$ 와 기둥 폭 외부에 위치한 비틀림응력 $\left({ }_{e} \tau_{t}\right)$ 은 Table 6 에 나타내었다.

Table 6 에서와 같이 비틀림 응력 $\left({ }_{e} \tau_{t}\right)$ 은 기둥 폭 내부 정착비가 약 $35 \%$ 인 $\mathrm{IJH}-2$ 실험체가 기둥 폭 내부의 정 착비가 약 $65 \%$ 인 IJH-1, 3 실험체에 비해 약 1.8 배, 1.5 배 정도 높게 나타났다. 이러한 높은 비틀림 응력은 Fig. 5(b) 의 균열상황에서와 같이 접합부의 기둥 폭 외부에서 균열 의 진행 방향 각도를 변화시키는 원인으로 판단된다.

또한 기둥 폭 내부의 동일한 정착비내에서는 철근을 더 많이 배치한 $\mathrm{IJH}-3$ 이 긴장재롤 더 많이 배치한 $\mathrm{IJH}-1$ 에 비해 약 1.2 배 정도 높게 나타나고 있으나, 이는 IJH-1 실 험체가 지지점 힌지의 작동 불량으로 내력의 감소 없이 부재각 $4 \%$ 까지 실험이 실시하였기 때문이다.

Table 6 Maximum transferred moment, torsional stress and calculated torsional strength

\begin{tabular}{c|c|c|c}
\hline Specimen & $\mathrm{IJH}-1$ & $\mathrm{IJH}-2$ & $\mathrm{IJH}-3$ \\
\hline \hline${ }_{e} M_{t}(t . m)$ & 5.1 & 9.1 & 6.1 \\
\hline$e^{\tau_{t}\left(\mathrm{kgf} / \mathrm{cm}^{2}\right)}$ & 109 & 195 & 130 \\
\hline${ }_{c \tau_{t}\left(\mathrm{kgf} / \mathrm{cm}^{2}\right)}$ & \multicolumn{3}{|c}{119} \\
\hline$e^{\tau_{t} /{ }{ } \tau_{t}(\%)}$ & 92 & 164 & 109 \\
\hline
\end{tabular}




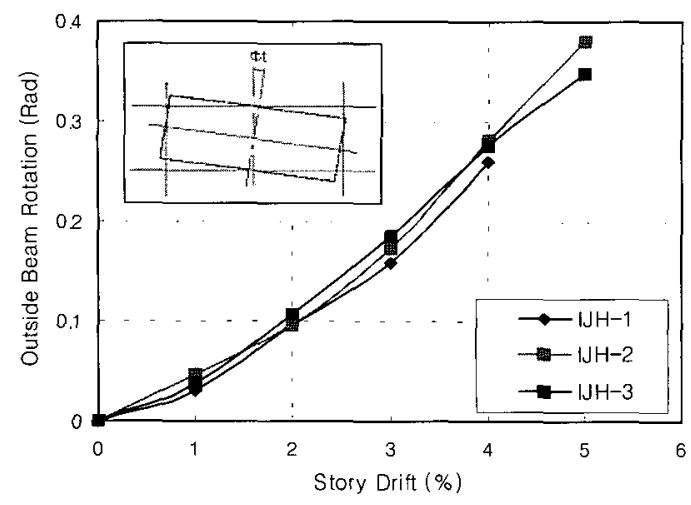

Fig. 9 Outside beam rotation

그러나 실혐장치가 정상적으로 작동하였다면 보의 단면 에서 높은 전단력 $\left(Q_{b}\right)$ 을 얻어 비틀림 응력은 유사하게 나 타났을 것으로 사료된다.

Fig. 9는 접합부의 기둥 폭 외부에서 넓은 보의 비틀림 변형에 의하여 나타난 기둥면과 넓은 보 사이의 미끄러짐 의 정도를 파악하고자 Hatamoto등이 이 일체식구조의 넓은 보-기둥 접합부 관련 연구에서 실시한 접합부의 기둥 폭 외부에서 기둥 축과 넓은 보의 회전각을 부재각에 따라 나타내었다. 가력초기부터 기둥 폭 외부에서 회전변형이 시작되었으며 부재각 $3 \%$ 까지는 거의 동일한 회전변형을 나타내었다. 그러나 $\mathrm{IJH}-2$ 실험체의 경우 4.1절의 파괴상 황에서 설명하였듯이 접합부의 기둥 폭 외부에서 기둥면 과 약 $45^{\circ}$ 의 대각선 방향으로 미소균열이 발생한 부재각 $3 \%$ 이후에는 다른 실험체에 비해 매우 선형적인 변형을 나타내었으며 종국에는 정착비가 $65 \%$ 인 $\mathrm{IJH}-3$ 실험체에 비해 약 1.2 배 이상 높게 나타났다. 또한 기둥 폭 내부의 정착비가 $65 \%$ 로 동일하지만 철근과 긴장재의 양을 달리 한 실험체에서는 긴장재보다 철근을 더 많이 배치한 $\mathrm{IJH}-3$ 에서 더 높은 회전변형을 나타내었다.

그러나 보/기둥 폭비와 기둥 폭 내부의 정착비가 본 연 구의 실험체 상세와 유사하며 포스트텐션을 도입하지 않 은 기존 연구 결과 ${ }^{3}$ 에 의하면 위에 나타난 실험결과와 딜 리 기둥 폭 내부의 정착비가 $33 \%$ 인 경우 기둥 폭 외부에 위치한 철근의 응력이 급격히 감소함으로서 하중-변위 이 력곡선에서 일부 핀칭현상과 함께 전체적인 내력감소를 나타내었다. 또한 접합부의 기둥 폭 외부에서 높은 회전변 형을 나타내고, 낮은 에너지 소산면적을 발휘하는 것으로 보고하고 있다. 반면 넓은 보에 포스트텐션을 도입한 PPS 공법은 위에서 언급한 일체식 구조의 넓은 보-기둥 접합 부와 달리 기둥 폭 내부의 정착비가 $35 \%$ 인 경우 다소 높 은 비틀림 응력을 나타내었으나 Fig. 8에 나타낸 누적 에 너지 소산면적과 Fig. 9에 나타낸 접합부의 기둥 폭 외부 에서 회전변형은 기둥 폭 내부의 정착비가 $65 \%$ 인 경우 와 거의 유사하게 나타나고 있음을 알 수 있다. 이는 기둥

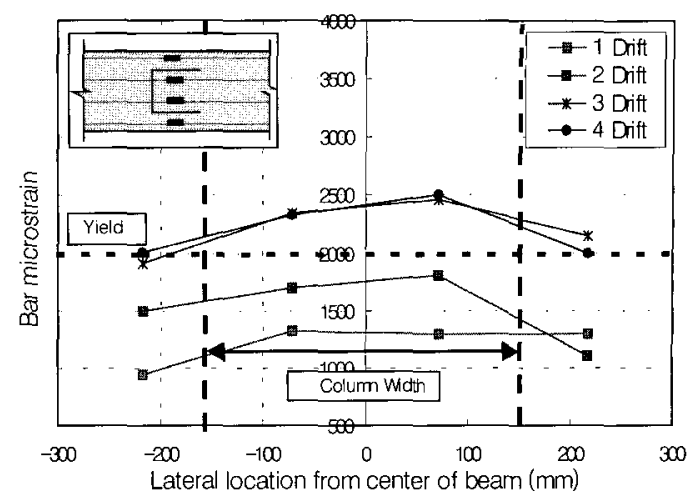

(a) $\mathrm{IJH}-1$

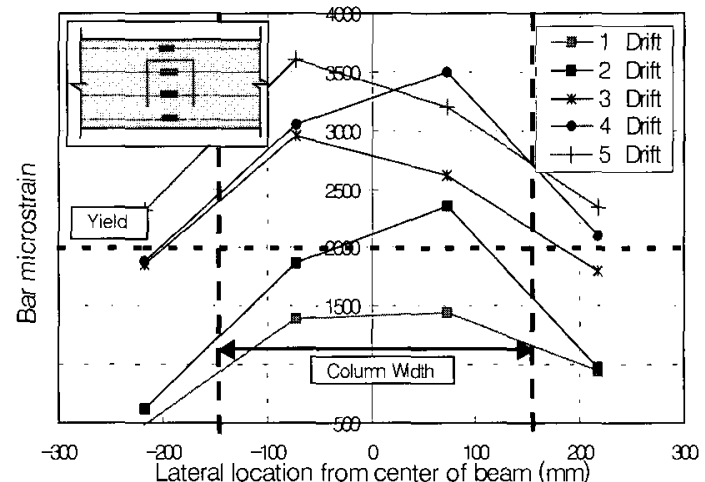

(b) $\mathrm{IJH}-2$

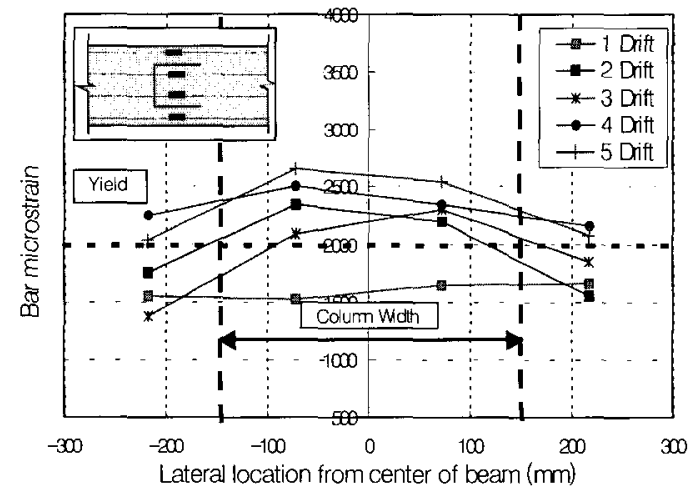

(c) $1 \mathrm{JH}-3$

Fig. 10 Strain distribution of top beam bars across beam width

폭 외부에 위치한 인장철근의 항복 이후 긴장재가 응력을 충분히 발휘함으로서 뚜렷한 하중의 감소현상이 나타나지 않으며 비탄성 이력거동을 통하여 에너지를 효과적으로 소산하였기 때문으로 판단된다.

\section{5 철근변형률}

프리스트레스를 도입한 넓은 보-기둥 접합부에서 넓은 보 의 거동 특성을 파악하고자 넓은 보 주근의 변형률을 측정하 였으며, 보의 단면에 따른 변형률의 분포는 Fig. 10과 같다. 
대체적으로 기둥 폭 내부의 철근은 하중 가력 초기부터 지속적인 변형률 증가를 나타내며 부재각 $2.0 \sim 2.5 \%$ 에서 항복하였으며 이후 부재각이 증가함에 따라 기둥 폭외부 의 모든 철근들도 항복하였다. 그러나 부재각에 따른 보의 주근에서 나타난 항복의 시기는 변수별로 다소 차이가 있 음을 알 수 있다. 기둥 폭 내부의 경우 정착비가 약 $35 \%$ 인 $\mathrm{IJH}-2$ 가 부재각 $2 \%$ 에서 항복한 반면, 기둥 폭 내부에 긴장재롤 더 많이 배치하여 정착비가 약 $65 \%$ 가 되도록 계획한 $\mathrm{IJH}-1$ 은 부재각 $3 \%$ 에서 항복하였다. 그러나 기둥 폭 외부에서의 변형률을 살펴보면, 기둥 폭 내부의 경우와 는 반대로 $\mathrm{IJH}-2$ 는 부재각 $3.5 \sim 4 \%$ 에 항복한 반면, $\mathrm{IJH}-1$ 는 부재각 $3 \%$ 에 항복함으로서 다소 먼저 항복함을 알 수 있다. 이는 기둥 폭 내부의 정착비가 높아짐으로서 기둥 폭 외부에 위치한 보강근의 응력부담이 가중되었기 때문으로 넓은 보에서 기둥 폭 외부에 위치한 철근들도 전체적 거동에 충분히 기여하고 있는 것으로 판단되었다.

기둥 폭 내부에 철근과 긴장재의 양을 다르게 하여 정착 비 약 $65 \%$ 을 만족한 $\mathrm{IJH}-1,3$ 의 경우 거의 유사한 거동 을 하였으나 폭 내부에서의 변형률을 보면 철근을 더 많 이 배치한 $\mathrm{IJH}-3$ 은 부재각 $2 \%$ 에서 항복한 반면 $\mathrm{IJH}-1$ 은 $3 \%$ 에서 항복하였다. 따라서 기둥 폭 내부에서 외부로의 응력배분은 긴장재가 더 유리한 것으로 판단된다.

결과적으로 기둥 폭 내-외부 각각의 위치에서 보강근 의 응력증가량은 긴장재 양이나 일반철근의 양이 증가할 수록 적게 나타나고 있다. 이는 긴장재의 극한응력에 영향 을 미치는 변수별 효과에 관한 기존연구 ${ }^{10)}$ 결과에서와 마 찬가지로 평형방정식에서 긴장재의 응력이 증가할수록 동 일한 인장력에서 한가닥의 긴장재에 발생하는 인장응력은 감소하고, 일반철근의 양이 증가할수록 긴장재가 부담하는 인장력이 감소하기 때문으로 판단되었다.

\section{6 접합부 전단응력계수}

ACI-ASCE 352에서 접합부의 설계개념은 비탄성 변형 에서도 강도가 유지되도록 한 모멘트 저항골조를 포함하 고 있으며, 콘크리트의 스트럿 메커니즘이 접합부 전단에 기여함을 나타내고 있다. 따라서 실험결과로부터 각 실험 체에 대한 전단응력계수를 평가하고 이의 적용성을 검토 하기 위하여 접합부의 공칭전단강도는 식 (6)을 이용하여 산정하였다.

$$
\begin{aligned}
& \phi V_{n} \geq V_{u} \\
& V_{u}=T_{u 1}+T_{u 2}-V_{\text {col }} \\
& V_{n}=\gamma \sqrt{f_{c k}} b_{j} h \quad(P s i) \\
& \gamma=\left(A_{s} \alpha f_{y}+A_{p s} f_{p y}-V_{c o l}\right) / b_{j} h \sqrt{f_{c k}}
\end{aligned}
$$

여기서, $\gamma$ : 접합부 전단응력계수, $A_{s}$ : 인장철근의 단면적

$A_{p s}$ : 긴장재의 단면적, $\alpha: 1.25$

$V_{c o l}$ : 기둥면의 전단력 (각 실험체의 최대강도)

$b_{j}$ : 접합부의 유효면적

$T_{u}: T_{u 1}+T_{u 2}$ (보강재의 인장력)

$\mathrm{ACI}-\mathrm{ASCE}$ 352에서 제한하는 접합부 전단응력계수는 각 실험체별 재료실험에 의한 철근과 콘크리트의 특성값 및 실험을 통하여 얻어진 최대내력을 이용하여 식 (7)에 적용하였으며, 그 결과는 Table 7과 같다. 그리고 각 실혐 체의 유효폭은 일반적인 보-기둥 접합부에서 적용하고 있 는 기둥과 보 폭 합의 $1 / 2$ 과 기둥폭으로 가정하였다.

그 결과 접합부의 유효폭을 기둥폭으로 가정했을 때 19.28 19.58로 $\mathrm{ACI}-\mathrm{ASCE} 352$ 의 제안값인 20 의 $95 \%$ 정 도로 매우 잘 일치하는 것으로 나타났다.

따라서 $\mathrm{ACl}-\mathrm{ASCE} 352$ 위원회의 규정에서 제한하는 일 체식 구조의 접합부 전단응력계수는 넓은 보와 $\mathrm{PC}$ 로 구 성되는 접합부 설계에도 활용할 수 있는 것으로 사료된다.

\section{7 구조성능평가}

현행 $\mathrm{ACI}$ 기준에서는 지진지역에서 $\mathrm{PC}$ 구조 또는 $\mathrm{PSC}$ 구조도 일체식 철근콘크리트 골조와 동등한 성능을 발휘 할 수 있음을 실험 혹은 이론적으로 증명하도록 되어 있 다. 본 연구에서 진행한 PPS 공법의 경우 $\mathrm{PS}$ 를 도입한 $\mathrm{PC}$ 구조로서 현행 $\mathrm{ACl}^{6}$ 에서 제안한 방법을 적용하여 일 체식 접합부와 동일한 성능을 발휘하는가를 평가하였다.

$\mathrm{ACI}$ 에서 제한된 $\mathrm{PC}$ 구조물의 모멘트 골조 구조성능의 허용기준에 관한 실험평가 방법의 내용을 정리하면 다음 과 같다. (Fig. 11 참조)

1) 부재각 $3.5 \%$ 에서 두 개의 완전한 싸이클 이후, 세 번 째 싸이클에서의 최대강도는 $0.75 E_{\max }$ 보다 커야 한다.

2) 부재각 $3.5 \%$ 의 세 번째 싸이클 이후, 상대에너지 소산 비양은 $12.5 \%$ 를 초과하여야 한다.

Table 7 Values of $\gamma$ for beam-column joints

((1) $: b_{i}=\left(b_{b}+b_{r}\right) / 2$. (2) $\left.: b_{i}=b_{r}\right)$

\begin{tabular}{c|c|c|c|c|c|c|c|c}
\hline \multirow{2}{*}{ Specimen } & \multirow{2}{*}{$P_{c r}(\mathrm{kN})$} & \multirow{2}{*}{$T_{u}(\mathrm{kN})$} & \multirow{2}{*}{$V_{u} / 0.85(\mathrm{kN})$} & \multicolumn{3}{|c|}{ Joint classification $(\gamma)$} & \multicolumn{3}{|c}{ Comparison } \\
\cline { 5 - 7 } & & & & $(1)$ & $(2)$ & ACI(3)) & $(1) /(3)$ & (2)/(3) \\
\hline \hline $\mathrm{IJH}-1$ & 85.3 & 810 & 852 & 14.69 & 19.58 & & 0.74 & 0.98 \\
\hline $\mathrm{IJH}-2$ & 87.2 & 810 & 848 & 14.63 & 19.5 & 20 & 0.73 & 0.97 \\
\hline $\mathrm{IJH}-3$ & 103.2 & 816 & 839 & 14.46 & 19.28 & & 0.72 & 0.96 \\
\hline
\end{tabular}


3) 부재각 $3.5 \%$ 의 세 번째 싸이클 이후, 부재각 0에서 수 평저항력은 $0.05 E_{\max }$ 보다 커야 하며 첫 싸이클의 0.05 배 보다 큰 강성을 가져야 한다.

따라서 이에 따른 허용기준의 만족여부를 확인하였으며 Fig. 12에서와 같이 모든 실험체가 만족스런 결과를 나타냄 으로서 지진시 PC U형의 넓은 보-기둥 접합부로 구성된 구조는 수평력에 대한 변형을 제어하는 것으로 퐌단되었다.

\section{5. 결 론}

프리스트레스를 도입하여 기둥 폭 내부의 정착비를 달 리한 넓은 보-기둥 접합부의 각 실험체에 대한 구조실험 을 통해 얻어진 결과는 다음과 같다.

1) 현행 $\mathrm{ACI}$ 에서 제한하는 넓은 보의 유.효폭내에서 본 연 구에서 실험된 기둥 폭 내부의 정착비가 35 65\%인 경우 연성적인 거동을 하며. 내력은 유사하게 나타났다.

2) 포스트텐션을 도입한 넓은 보-기둥 접합부는 연성적인 거동을 나타내며, 변위연성비는 기둥 폭 내부의 정착 비와 관계가 적은 것으로 나타났다.

3) 넓은 보에 포스트텐션을 도입한 PPS 공법은 기둥 폭 내부의 정착비가 $35 \%$ 인 경우 다소 높은 비틀림 응력 을 나타내었으나 기둥 폭 외부에 위치한 인장철근의

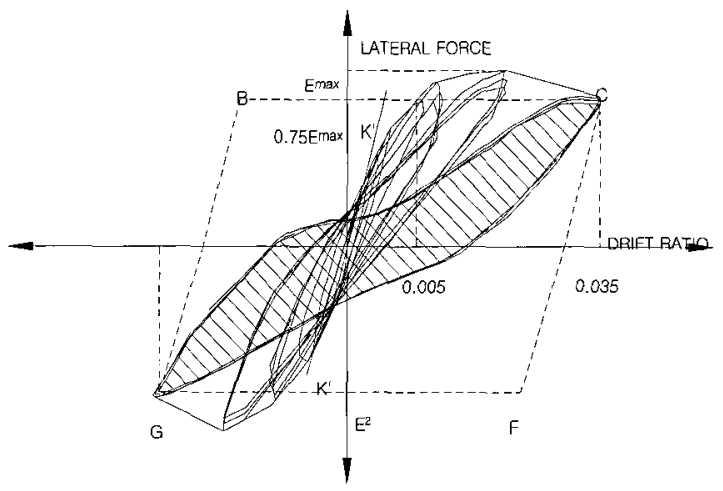

Fig. 11 Acceptance criteria (by Hawikins)
항복 이후 긴장재가 응력을 충분히 발휘함으로서 일체 식 구조의 넓은 보-기둥 접합부와 달리 비탄성 이력거 동을 통하여 에너지를 효과적으로 소산하였다.

4) 기둥 폭 내·외부 각각의 위치에서 보강근의 응력증가 량은 긴장재 양이나 일반철근의 양이 증가할수록 적개 나타났다.

5). 일체식 콘크리트 구조의 접합부 설계에 관한 $\mathrm{ACI}-$ $\mathrm{ASCE} 352$ 위원회의 규정에서 제한하는 접합부 전단응 력계수는 본 연구의 실험결과와 비교적 정확하게 일치 함으로서 넓은 보와 $\mathrm{PC}$ 로 구성되는 접합부설계에도 활용할 수 있는 것으로 판단된다.

6) 기둥 폭 내부의 정착비를 달리한 넓은 보-기둥 접합 부의 내진성능은 NEHRP에서 제안한 성능평가 방법에 의해 분석한 결과, 만족할 만한 결과를 얻을 수 있었다.

\section{감사의 글}

본 연구는 삼성물산(주), $\mathrm{BDG}$ (주), 한양대학교 초대형구 조시스템 연구센터의 연구비 지원과 고려제강(주)의 긴장 재 지원을 받아 수행한 연구의 일부로 이에 감사드립니다.

\section{참고 문헌}

1. 삼성물산(주), "PPS 공법의 실용화 기술개발에 관한 연 구”, 삼성물산(주), Jul. 2003.

2. T. Russell Gentry and James K. Wight, "Wide Beam-Column Connections under Earthquake-Type Loading," Earthquake Spectra, Vol.10, No.4, 1994, pp. $675 \sim 703$.

3. Hatamoto, H., Bessho, S., and Matsuzaki, Y., "Reinforced Concrete Wide Beam to-Column Subassemblages Subjected to Lateral Load," Design of BeamColumn Joints for Seismic Resistence(ACI Publication SP-123), American Concrete Institute, Detroit, Michigan, 1991, pp.291 316.

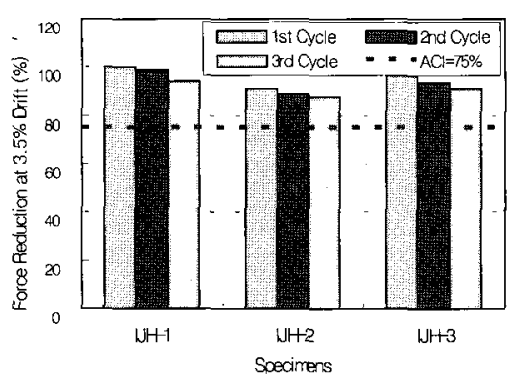

(a) Force reduction ratio

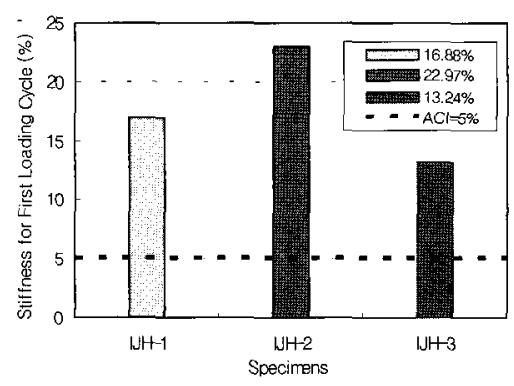

(b) Secant stiffness

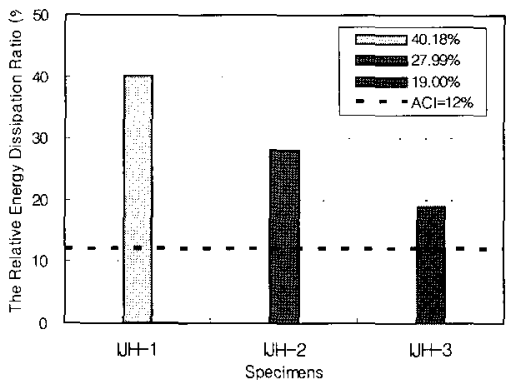

(c) Relative energy dissipation ratio

Fig. 12 Estimation of structure performance 
4. John S. Stehle, Helen Goldsworthy, and Priyan Mendis., "Reinforced Concrete Interior Wide-Band Beam-Column Connections Subjected to Lateral Earthquake Loading," ACI Structural Journal, MayJun. 2001, pp.270 279.

5. Slab-Column Connections Transferring Shear and 5. W. L. Siah, Priyan Mendis, and John S. Stehle, "Seismic Performance of Interior Post-Tensioned Concrete Wide Beams" ACI Structural Journal, May-Jun. 2003, pp.283 290.

6. ACI Innovation Task Group 1 and Collaborators, "Acceptance Criteria for Moment Frames Based on Structural Testing (T1.1R-01),"American Concrete Institute, Farmington Hills, MI, 2001, 10pp.
7. ACI committee 352, "Recommendations for Design of Beam Column Joints in Monolithic Reinforced Concrete Structures(352R-91)," ACI, detroit, 1997.

8. NZS 3101, "The New Zealand Standard for the Design of Concrete Structures," Standard Association of New Zealand, Wellington, New Zealand, 1995.

9. Yoshikazu Kanoh and Seiji Yoshizaki, "Strength of Slab-Column Connections Transferring Shear and Moment," ACI Structural Journal, March. 1979, pp. $461 \sim 478$.

10. 임재형외, “비부착 긴장재의 응력에 영향을 미치는 중 요변수에 대한 실험연구", 콘크리트학회지, 11 권 1호, 1999, 2, pp.209 219.

\section{요 약}

PPS(post-tensioned precast concrete system)공법은 U자형 PC로 제작한 넓은 보와 PC 또는 현장 타설 콘크리트로 제작한 기둥으로 구성되며 PC 보와 기둥의 일체성 확보를 위하여 프리스트레스를 도입하였다. 본 연구는 PPS 공법 개발의 일부로 넓 은 보의 기둥 폭 내부에 정착되어진 횜철근의 양에 따른 거동특성을 분석하고자 실험적 연구를 수행하였다. 실험체는 기둥 폭 내, 외부에 위치한 휨 철근의 양을 달리한 정착비와 동일한 정착비내에서 철근과 긴장재의 양을 주요변수로 하여 대상건물의 내부접합부를 대상으로 $1 / 2$ 크기로 제작하였다.

그 결과 NEHRP 권고사항에서 규정한 한계변위각 0.035 까지 내력저하 없이 충분한 내력을 보유하였으며, 보의 휨 파괴가 주 요 파괴모드로 접합부에서 전단파괴는 일어나지 않았다. 그리고 넓은 보에 포스트텐션을 도입한 PPS 공법은 기둥 폭 내부의 정착비가 $35 \%$ 인 경우 다소 높은 비틀림 응력을 나타내었으나, 기둥 폭 외부에 위치한 인장철근의 항복 이후 긴장재가 응력을 충분히 발휘함으로서 일체식 구조의 넓은 보-기둥 접합부와 달리 비탄성 이력거동을 통하여 에너지를 효과적으로 소산하였다. 또한 $\mathrm{ACI}$ 의 proposed provisional standard의 $\mathrm{PC}$ 접합부 구조성능 평가지침에 의해 분석한 결과, 모든 실험체에서 허용기준을 모두 만족하고 있으며, 강도의 큰 저하 없이 연성적인 거동을 하고 있음을 알 수 있었다.

핵심용어 : 포스트텐션, 프리캐스트, 넓은 보, 보-기둥 접합부 